\title{
Auditors' Usage of Non-Financial Data and Information during the Assessment of the Risk of Material Misstatement for an Audit Engagement: A Field Study
}

\author{
Abdelmoneim A. Awadallah', Ph.D. \& Haitham Mohamed El-Said², Ph.D. \\ ${ }^{1}$ Professor of Managerial Accounting and Economics, The Accounting Department, Faculty of Commerce, Cairo \\ University, Egypt \\ 2 The Accounting Department, Faculty of Commerce, Cairo University, Egypt \\ Correspondence: Haitham Mohamed El-Said, The Accounting Department, Faculty of Commerce, Cairo University, \\ Egypt
}

Received: September 23, 2017

Accepted: October 26, 2017

Online Published: November 1, 2017

doi:10.5430/afr.v7n1p13

URL: https://doi.org/10.5430/afr.v7n1p13

\begin{abstract}
Audit firms that fail to detect fraud or material misstatements in the financial statements of their audit clients may suffer substantial monetary penalties and negative publicity in the event of audit failure. The present study investigates auditors' perception regarding the use of non-financial data and information to verify the validity of financial data and information reported by an audit client during an audit engagement. In addition, the current study considers the sources of information that auditors may depend on when searching for explanations for unusual trends in the financial statements of an audit client. The present study is based on a field study conducted in Egypt during the year 2014.

Using a questionnaire supplemented by in-depth interviews, the present study showed that auditors are likely to make moderate use of non-financial data and information when assessing the risk of material misstatements during an audit. However, it seems that auditors prefer to depend on financial data and information more than non-financial data and information when developing expectations about account balances during an audit engagement. Furthermore, the present study pointed out that auditors appear to rely more on inquiries of audit client personnel than other sources of information when searching for explanations for unexpected trends in the financial statements of an audit client.
\end{abstract}

Keywords: Analytical Procedures, Non-financial Data and Information, Risk of Material Misstatement, Egypt

\section{Introduction}

By audit standards (e.g., Statement on Auditing Standards (SAS) no. 56 and International Standard on Auditing (ISA) no. 315), auditors are required to perform analytical procedures during the planning stage of an audit in order to understand the business environment of the audit client and to assess the various risks associated with the performance of an audit. SAS No. 56 indicated that analytical procedures entail consideration of both financial and non-financial data and information (AICPA, 1988). Financial data and information are usually obtained directly from the financial statements of an audit client, such as net income and financial ratios. Non-financial data and information are not usually contained on the face of the financial statements of an audit client, but may be disclosed elsewhere in the annual report, or produced and reported by independent sources, such as industry trade groups (Brazel, Jones, \& Prawitt, 2014). Examples of non-financial data and information include the number of facilities, retail outlets, warehouses, general economic conditions, and market share of the audit client.

Auditors usually develop expectations about the financial position of an audit client by understanding how the economic environment affects the financial statements of this audit client (Brewster, 2011). SAS no. 99 (AICPA, 2002, p.28) states:

"In performing analytical procedures ... the auditor develops expectations about plausible relationships that are reasonably expected to exist, based on the auditor's understanding of the entity and its environment. When comparison of those expectations with recorded amounts yields unusual or unexpected relationships, the auditor should consider those results in identifying the risk of material misstatement due to fraud." 
Prior research argued that auditors' analytical procedures based on financial data only seem to be ineffective at detecting fraud in the financial statements of an audit client (Brazel, Jones, \& Zimbelman, 2009). For example, if a company is smoothing earnings, then current year financial data could be manipulated to appear consistent with prior year data. As a result, if auditors are performing analytical procedures that depend on financial data only, they may not discover that the company's financial statements are misstated. Since the manipulated financial data, in this case, would yield auditors' expectations that confirm the company's accounts balances and require no further attention from the auditors (Trompeter \& Wright, 2010).

It is claimed in the literature that non-financial data and information could be used to help auditors understand a client's business by pointing them to the drivers of economic performance of an audit client (Ittner \& Larcker, 1998). Similarly, if non-financial data and information exist that are easily verified and are not being manipulated by management, then using non-financial data and information would provide an avenue for auditors to both generate reliable expectations for analytical procedures and test the validity of management's explanations for their inquiries (Brazel et al., 2009). Thus, identifying inconsistencies between financial data and related non-financial data would serve as a red flag for auditors, leading them to ask pointed questions to the management of the audit client, test management's responses with reliable evidence, increase auditors' professional skepticism, and assign required specialists to the audit engagement (Brazel et al., 2014).

However, prior research emphasized that auditors tend to rely heavily on financial data and information when assessing the risk of material misstatement during an audit (Erickson, Mayhew, \& Felix, 2000; Cohen, Krishnamoorthy, \& Wright, 2000; Trompeter \& Wright, 2010; Brazel et al., 2014). Accordingly, auditors may fail to recognize unusual trends and/or ratios within the financial statements of an audit client that may serve as a sign of the existence of misstatements (Brazel et al., 2009). In addition, previous research showed that auditors generally do not self-generate explanations for unusual trends and ratios uncovered in the financial statements of their audit clients and they tend to depend on the explanations provided by the staff members of the audit client without performing sufficient work to test the validity of the explanations provided by the client personnel (Hirst \& Koonce, 1996; Trompeter \& Wright, 2010).

The present study aims at investigating the perception of auditors regarding the use of non-financial data and information to verify the validity of the financial data reported by an audit client when assessing the risk of material misstatement during the planning stage of an audit. In addition, the present study looks at the sources of information that an auditor would depend on to find explanations for unexpected trends and/or ratios that may exist in the financial statements of an audit client. The present study is based on a questionnaire supplemented by in-depth interviews conducted with auditors working at the branches of the international big four auditing firms in Egypt during the year 2014. Egypt was chosen as a site for the present study because of the unfavorable economic conditions in Egypt during the 3 years following the revolution of January 2011. The state of the Egyptian economy appears to have increased the business risks faced by firms operating in Egypt and provided particular challenges to all parties involved in auditing and preparing annual reports of financial statements. The results of the present study show that auditors seem to be making moderate use of non-financial data and information during the assessment of the risk of material misstatement for an audit engagement. Despite that, it appears that auditors prefer to depend on financial data and information more than non-financial data and information when developing expectations for the account balances of their audit clients. Besides, client personnel inquiry is found to be the most frequently used source of information by auditors to search for explanations for unusual trends in the financial statements of an audit client. The respondents mentioned during the interviews that they usually perform further investigations (such as tests of details of balances and/or transactions) to evaluate the reasonableness of the answers received from the staff of the audit client before accepting them.

The remainder of this paper is organized as follows: Section (2) presents a literature review and research questions. Section (3) highlights the economic conditions of Egypt during the period following the revolution of January 2011. Section (4) demonstrates the research method and data collection procedures. Section (5) shows the findings of the current study. Section (6) includes a summary and concluded remarks of the present study. Section (7) contains current research limitations and suggestions for future research.

\section{Literature Review and Research Questions}

\subsection{The Role of Non-Financial Data and Information in Verifying the Financial Performance of an Audit Client}

Auditors usually assess risks related to audit clients (including financial risk, audit risk, and auditor business risk) before entering into an audit engagement with them (Note 1). The main reason for investigating a new or continuing audit client is to ascertain the integrity of the client's management and evaluate potential litigation and reputation 
costs that may be incurred by the auditor in case of audit failure (DeFond, Lim, \& Zang, 2016; Johnstone \& Bedard, 2004).

It is argued in the literature that considering non-financial data and information in conjunction with financial data and information may help auditors in the assessment of the risk of material misstatement (Cohen et al., 2000; Bell, Peecher, \& Solomon, 2005; Knechel, 2007; Brazel et al., 2009). Prior studies mentioned that using non-financial data and information in association with financial data and information would help auditors detect signals of fraudulent financial reporting and make it difficult for the management of an audit client to conceal fraud (Brazel et al., 2009; Brazel et al., 2014). Cohen et al. (2000) mentioned that auditors make more use of non-financial information when generating hypotheses to explain unexpected fluctuations within the financial statements of an audit client than when determining audit scope. The Public Company Accounting Oversight Board (PCAOB) has discussed the potential for non-financial information to provide independent benchmarks for evaluating the validity of financial statements data (PCAOB, 2004). The PCAOB concluded that analytical procedures using only financial data are likely to be ineffective for detecting fraud because management can make fictitious entries to financial data in order to create an expected pattern of the results of operations of an entity (PCAOB, 2004).

To serve as an effective benchmark for evaluating financial data, non-financial information must be correlated with the performance reflected in the financial statements of an audit client. Previous studies supported that non-financial measures are usually associated with the financial performance of audit clients and could be used to uncover unexpected trends in the financial statements of audit clients (Riley, Preason, \& Trompeter, 2003; Brazel et al., 2009, Bell, Marrs, Solomon, \& Thomas, 1997). For example, Behn and Riley (1999) found that non-financial measures in the airline industry (e.g., on-time performance and load) may be useful for predicting quarterly revenue, expense, and net income. Nagar and Rajan (2001) documented the usefulness of manufacturing quality measures in predicting future revenue. Simpson (2010) found that a number of wireless industry-specific non-financial measures have a significant predictive ability for future earnings. Brazel et al. (2009) indicated that for fraud firms the percentage of growth in sales revenue differs substantially from the percentage of growth in non-financial measures related to capacity. Dechow, Ge, Larson, \& Sloan (2011) observed that assets growth for fraud firms differs significantly from the growth in the number of employees for these firms. Moreover, audit guidance suggests that non-financial data and information could be used to verify financial results of an audit client. SAS No. 99 explicitly advises auditors to compare high-risk account balances (e.g., revenue) to capacity-related non-financial measures (AICPA, 2002). For example, if the growth of sales revenue for an audit client is substantially exceeding its production capacity then this may indicate that fictitious sales have been recorded. Thus, it seems that there is a reason to believe that auditors' consideration of non-financial data and information may lead to a relative improvement in the assessment of the risk of material misstatement during an audit engagement.

Nevertheless, results of several studies raised the possibility that auditors' attention to non-financial data and information is insufficient to detect fraudulent financial reporting (Brazel et al., 2014). Hirst and Koonce (1996) documented that auditors in the past did not use non-financial data and information during the performance of analytical procedures. Trompeter and Wright (2010) extended the work of Hirst and Koonce (1996) and mentioned that auditors reported moderate use of non-financial data and information during the performance of analytical procedures, but still prefer to depend on prior years account balances when developing expectations for current year account balances. Brazel et al. (2014) documented that only a minority of senior auditors choose to depend on non-financial measures when evaluating revenue account balances via analytical procedures. Previous research conducted mainly in developed countries emphasized that auditors may tend not to use non-financial data and information because of budgetary pressures, lack of easy availability, over-reliance on prior years working papers that do not include analyses of non-financial data and information, or a lack of understanding about the non-financial measures that drive company performance (Wright, 1988; Houston, 1999; Erickson et al., 2000; Brazel et al., 2004).

Prior studies conducted in Egypt showed that auditors appear not to make extensive use of non-financial data and information during an audit engagement due to lack of experience and training to use non-financial information, limited disclosures of non-financial information by Egyptian firms, and pressures to reduce audit costs and fees as a result of competition (Hassan, Giorgioni, \& Romilly, 2006; Wahdan \& Van den Herik, 2012). Hassan \& Power (2009) examined whether financial analysts in Egypt view accounting information (whether disclosed or not) in corporate annual reports as valuable for investment decision making. The findings indicated that financial analysts value quantitative information more than non-quantitative information when developing forecasts for stock prices in the Egyptian capital market. Hassan \& Power (2009) pointed out that non-quantitative items of information are usually voluntary disclosed by Egyptian firms and some of this information has never been actually disclosed in Egyptian financial statements. Marzouk (2016) examined corporate risk disclosure practices and determinants in the 
annual reports of Egyptian companies during the 2011 political crisis in Egypt. The results showed that companies disclosed more quantitative than qualitative risk information in their annual financial reports during the 2011 political crises in Egypt.

Based on the results of prior studies, the first research question may be expressed as follows:

RQ1: Do auditors in Egypt make use of non-financial data and information during the assessment of the risk of material misstatement to evaluate the validity of the financial data and information reported by audit clients?

2.2 The Importance of Understanding the Business Environment of Audit Clients to Find Explanations for Unusual Trends in the Financial Statements

Authoritative guidance on external auditing addressed the importance of understanding an audit client business during the performance of an audit. The International Auditing and Assurance Standards Board (IAASB) issued the ISA no. 315: "Identifying and assessing the risks of material misstatement through understanding the entity and its environment". ISA no. 315 required auditors to identify and assess the risk of material misstatement in the financial statements through an understanding of the audit client entity and environment, including the entity's internal controls and risk assessment process (IAASB, 2010).

Audit standards require auditors to have an understanding of the client's business environment, by gathering information about the general economic trends and industry conditions, the impact of competition, compliance with laws and regulations, strategies and plans, and critical internal business processes of the audit client (IAASB, 2010). Auditors could source this information by reading industry trade publications, regulatory requirements, minutes of the board of directors and significant contracts of the audit client. Auditors may need to identify factors such as major sources of income, key customers and suppliers, sources of finance, and transactions with related parties requiring disclosure. An auditor should also read the audit client financial statements, perform ratio analysis, and inquire about key performance indicators the client's management is using to measure progress toward its objectives (IAASB, 2010). The idea is to link the auditor's understanding of a client's business environment to the analysis of audit risk.

Knechel, Salterio, \& Kochetova-Kozloski (2010) pointed out that auditors could compare their client's profitability, liquidity, leverage, and growth measures arising from financial statements analyses with performance measures of similar companies working in the same economic and market conditions. Such comparisons of performance measures would provide insight not only into future shareholders return but also into any risk related to potential unethical behavior, including questionable earnings management techniques.

Based on the information gathered and analyses performed, auditors may find trends in the financial statements of an audit client that seem to be uncommon based on their understanding of the client's business and industry conditions. In such cases, auditors may need to search for explanations for such unusual trends from different sources. Examples of sources of information that may be approached by an auditor include asking other members of the audit team, generating self-explanations, checking prior years' work papers, and inquiring the client personnel. Results of Hirst and Koonce (1996), as well as Trompeter and Wright (2010), indicated that client personnel inquiry is the primary source of information used by auditors to find explanations for unexpected results got from analytical procedures during the planning of an audit. Of course, this would be a matter of concern if auditors do not subject the explanations of the client personnel to further investigation to check its reasonableness. Trompeter and Wright (2010) mentioned that some of the respondents of their study stated that they may seek supporting information to verify the reasonableness of the explanations received from the audit client personnel. Such supporting information could include industry data, prior experience with the client, obtain third party corroborating evidence, and perform further testing. Therefore, the second research question is:

RQ2: What sources of information do auditors in Egypt depend on to find explanations for unexpected trends in the financial statements of an audit client?

\section{The Economic Conditions of Egypt during the Period Preceding the Present Study}

Egypt is one of the emerging economies in Africa and the Middle East. Egypt faced deteriorating economic conditions during the three years following the revolution of January 2011. The Egyptian economy was affected negatively by the unstable political conditions and continuous strikes following the revolution of January 2011. The Egyptian economy was expected to grow at a rate of six percent during the fiscal year of 2010/2011 (just before the revolution of January 2011). However, growth forecasts were revised to two percent after the revolution of January 2011. International credit rating agencies downgraded Egypt's government bond ratings many times during the three years following the Egyptian revolution of 2011. Egyptian banks became reluctant to finance business activities 
because of the fear that funds may not be returned as a result of a seemingly economic recession. Moreover, customers' purchasing power declined as a result of inflation which was running around 15 percent per year. Business entities working under such uncertain economic conditions faced difficulties in maintaining profitable trading levels and generating sufficient cash flows to manage working capital requirements. The impact of such economic conditions also affected the ability of some business entities to continue, and thus, affected their going concern status. In turn, the state of the Egyptian economy and its impact on enterprises, directly or indirectly, provided particular challenges to all parties involved in auditing and preparing annual reports of financial statements. Auditors are required to pay attention to the increased business risk of their audit clients and its effect on the assessment of audit risk when performing an audit under such unfavorable economic climate. Auditors should gather adequate data and information about their audit clients to be able to verify the validity of the financial results reported by those clients and to find justifications for any unusual trends.

\section{Research Method and Data Collection Procedures}

\subsection{The Development of the Research Method and Pilot Testing Phase}

The current study is based on a questionnaire that was developed by the authors during the last quarter of the year 2013. The questionnaire consists primarily of structured questions which are supplemented with semi-structured questions to further explore the respondents' perception about the research topic. The questionnaire instrument aimed at helping the respondents express their opinions either through a five-point scale where $1=$ Rarely, $2=$ Sometimes, 3 $=$ Usually, $4=$ Frequently, and $5=$ Always, or yes/no questions in addition to open-ended questions. Furthermore, the questionnaire was supplemented by in-depth interviews with the respondents to discuss in more detail aspects related to the questions of the questionnaire. Pilot testing of the questionnaire was conducted in Egypt during November 2013. The pilot testing phase involved in-depth interviews with five participants working in the auditing field in Egypt. The pilot testing resulted in some modifications to the questionnaire which were considered in the final version of the questionnaire.

\subsection{The Sample and Data Collection Procedures}

The present study depends on the responses of auditors working at branches of the international big four auditing firms engaged in audit works in Egypt (i.e. Ernst \& Young, KPMG, Price Waterhouse Coopers, and Deloitte Touche). The authors assume that depending on the responses of auditors working at the branches of the big four auditing firms would enhance the creditability of the findings of the present study. This is because branches of the big four auditing firms seem to use the same (more or less) quality control policies and procedures in auditing used by their headquarters worldwide. The personnel working at the branches of the big four auditing firms are assumed to have well designed and organized training courses on a continuous basis to enhance their experience and work capabilities. Furthermore, the branches of the big four auditing firms located abroad are likely to be constantly subject to peer review from their headquarters to determine whether or not these branches meet the quality control standards set for them in each audit engagement. Thus, it is assumed that the experience of the personnel, as well as the level of audit quality provided by the branches of the big four auditing firms, would be relatively higher than non-big four auditing firms.

The total number of respondents of the current study is 40 auditors working at the branches of the international big four auditing firms in Egypt. Table (1) shows the sample composition for the present study. The average audit experience of the respondents is 12 years. All the meetings with the respondents were held in 2014.

Table 1. Sample Composition

\begin{tabular}{lcc}
\hline Audit title & Frequency & Percent $(\%)$ \\
\hline Senior auditors & 25 & 62.5 \\
Audit managers & 9 & 22.5 \\
Partners & 6 & 15 \\
Total & 40 & 100 \\
\hline
\end{tabular}

The second author contacted the auditors by phone and/or e-mail in order to check the available time of the auditors to fill the questionnaire and perform the interviews. The meetings with the auditors usually start by providing a brief explanation about the present study and then asking them to fill the questionnaire. After the auditor completes the questionnaire, the second author performs an interview with the auditor regarding the issues discussed in the questionnaire. The duration of each meeting with the auditors ranged from 60 to 90 minutes. The interviews were 
audiotaped and then transcribed. The interviews helped the authors to find justifications for the auditors' responses to the questionnaire.

It should be mentioned that the authors faced a problem in relation to the collection of the data for the present study which is the lack of free time for auditors to fill the questionnaire and perform interviews due to their highly condensed operating time schedules. This left the vacations and the gaps between audit seasons as the only available time for the auditors to fill the questionnaire and conduct interviews.

\section{Results and Discussions}

This section presents the results of the present study. In the presentation of the results of the present study, the questions of the questionnaire are referred to as (Q) so that Q1 refers to question number 1, Q2 refers to question number 2 and so on.

5.1 Auditors' Reliance on Non-Financial Data and Information When Assessing the Risk of Material Misstatement during the Planning Stage of an Audit

Four questions (from Q1 to Q 4) were directed to the participants requesting them to express on a five-point scale (where 1 = rarely, $2=$ sometimes, $3=$ usually, $4=$ frequently, and $5=$ always) the extent to which auditors take into consideration data and information related to each of the following during the planning of an audit:

- The market share of the audit client (Q1).

- The competitors of the audit client (Q2).

- The general economic trends and industry conditions (Q3).

- The relationships of the audit client with its customers (Q4).

The mean of the respondents' responses regarding the above-mentioned four questions is presented hereunder in a descending order (see table 2).

Table 2. The Mean of the Respondents' Responses Regarding the Use of Non-Financial Data and Information During the Assessment of the Risk of Material Misstatement.

\begin{tabular}{ll}
\hline & Mean \\
\hline General economic and industry conditions (Q3) & 3.98 \\
Market share of the audit client (Q1) & 3.85 \\
Customers relations of the audit client (Q4) & 3.42 \\
Competitors of the audit client (Q2) & 3.10
\end{tabular}

Based on the auditors' response to the above-mentioned four questions it may be said that, auditors are likely to consider data and information associated with the general economic trends and industry conditions as well as the market share of the audit client more than data and information related to the client's competitors or customers relations when evaluating the risk of material misstatement. This result is to some extent consistent with the findings of prior research. Trompeter and Wright (2010) mentioned that 50 percent of their field study participants indicated that they incorporate knowledge of changes in the economy and industry conditions when performing analytical procedures for an audit client. On the other hand, Cohen et al. (2000) examined whether auditors respond to divergent trends between company financial data and non-financial data related to industry, market, or general economic conditions. Cohen et al. (2000) found mixed evidence regarding auditor attention to non-financial data during the planning phase of an audit.

During the interviews, the respondents expressed that as result of the uncertain economic conditions in Egypt after the revolution of January 2011, they tend to pay attention to the changes in the economic conditions (e.g., inflation rate and foreign exchange rates) and to consider the expected effect of such changes on the business environment of their audit clients. Furthermore, respondents indicated that they usually refer to relevant industry publications to be aware of any updates in the industry of the audit clients. Furthermore, the respondents mentioned that sometimes it may be difficult to obtain data and information related to the competitors of an audit client (such as key performance indicators used by competitors) because such data and information are usually not disclosed anywhere. Moreover, most of the respondents indicated that they may consider the data and information related to the customers of the audit client during their investigation of the sales and collection cycle. 
In question 5, respondents were asked: If non-financial data and information of a new audit client are declining, will you accept this new audit client? Participants were informed that the non-financial data and information meant for this question include the number of facilities, retail outlets, warehouses and employee headcounts (Q5).

For this question, the authors decided to consider only the opinions of the audit managers and partners as they are usually involved in the decisions of accepting or rejecting new audit clients. Eighty percent of the respondents for this question (12 out of 15 audit managers and partners) stated that they would accept a new audit client with a declining non-financial data and information. During the interviews, most of the participants indicated that declining trends of non-financial data and information of an audit client does not necessarily mean that the audit client is committing fraud or having misstatements in its financial statements. Hence, the declining trends of non-financial data and information may not lead to the rejection of an audit client given the deteriorating economic conditions in Egypt as discussed earlier in this study. However, most of the respondents indicated that they would perform more audit work (e.g., analytical procedures, tests of details of balances and/or transactions) to be satisfied that the financial statements of the audit client are not materially misstated.

Question 6 included the following: If you were to use non-financial measures (e.g., number of employees or number of outlets) to develop an expectation for an account balance, to what extent would you test controls and verify data to make sure that non-financial data and information were accurate? Use five-point scale $(1=$ rarely, $2=$ sometimes, $3=$ usually, $4=$ frequently, and $5=$ always) (Q6).

The mean of the respondents' responses for this question was 3.58 and the median was 3.5. This result seems to indicate that auditors usually check the reliability of non-financial data and information used in developing expectations for an account balance during an audit. A question similar to Q6 of the present study was asked to the participants of Brazel et al. (2014) study. Responses of the participants in Brazel et al. (2014) study were recorded on a scale ranging from 1 (None) to 10 (Extensively). The mean of the responses in Brazel et al. (2014) study was 6.92, indicating that auditors would likely determine that non-financial measures used by them during an audit were reliable. Most of the respondents of the present study pointed out that it is important to test the reliability of the non-financial information before depending on such information in developing expectations about the financial statements of an audit client in order to avoid any misleading judgments.

In question 7, respondents were asked if they compare financial and non-financial data and information of their audit clients to find out any conflicting trends between them during the assessment of the risk of material misstatement (Q7). All the respondents answered this question by "yes" indicating that they compare financial data and information with non-financial data and information during the assessment of the risk of material misstatement for an audit engagement. Then, respondents were requested to express on a five-point scale (where $1=$ rarely, $2=$ sometimes, 3 = usually, 4 = frequently, and 5 = always) to what extent they perform comparisons between financial and non-financial data and information to find out any conflicting trends between them. The mean of the participants' responses was 3.7 and the median was 4 . This result shows that auditors seem to perform comparisons between financial and non-financial data and information to find out if there are any inconsistencies between them during the assessment of the risk of material misstatement for an audit client. However, some respondents mentioned during the interviews that the existence of inconsistencies between financial and non-financial data and information of an audit client does not necessarily lead auditors to judge that the audit client is committing fraud or having material misstatements in its financial statements. Respondents expressed that when they uncover inconsistencies between financial and non-financial data and information, they tend to investigate the matter closely by performing tests of details of balances and/or transactions before judging that the financial statements are materially misstated. Thus, it may be said that auditors appear to depend on comparisons between financial and non-financial data and information to highlight areas where more audit work should be directed.

Participants were asked in Q8, if they have ever discovered errors or misstatements through the analyses of financial and non-financial data and information that otherwise would not have been discovered.

Forty-five percent of the respondents said "yes" and fifty-five percent responded by "no". Respondents who said "yes" were requested to give examples of misstatements or errors that were discovered. Some of the examples provided by the respondents include:

- Misclassification of assets: One respondent pointed out that during the audit of a mobile service provider company it was discovered that some of the telecommunication equipment were classified as fixed assets while these assets should have been expensed. Such misstatement resulted in the overstatement of the fixed assets and overstatement of the company profits by reducing expenses. 
- Sales misstatements: One of the respondents mentioned that an audit client working in retail services registered high sales in the last month of the fiscal year and irregular sales returns at the beginning of the following year to overstate sales.

- Overstatement of expenses: A respondent declared that during an audit and while checking the employees register it was realized that some workers resign from the company but their wages were paid for months after the date of resignation.

- Recording unearned revenue as earned: Some respondents indicated that in some cases companies tend to record revenue related to goods or services that are not provided yet by the company as realized revenue. However, unearned revenue is a current liability which represents payment received from customers against which no goods were delivered or services performed.

\subsection{Developing Expectations for Account Balances}

The respondents were requested to identify what audit techniques are most used by them when developing expectations about the balances of each of the operating costs and general expenses account and capital gains and losses account. The respondents were asked the same question twice for each of the operating costs and general expenses account and capital gains and losses account: one time for new audit clients and another time for continuing audit clients. Respondents were required to express using a five-point scale (where $1=$ rarely, $2=$ sometimes, $3=$ usually, $4=$ frequently, and $5=$ always) the extent to which they depend on each of the following five audit techniques in developing their expectations for account balances:

- Comparisons of balances.

- Analysis of ratios.

- Consideration of non-financial data and information.

- Budgets and forecasts prepared by the client.

- Interim data.

\subsubsection{Operating Costs and General Expenses Account Expectations}

Concerning the development of expectations for the operating costs and general expenses account for new audit clients (Q9), the mean of the participants' responses was 4.53 for comparisons of balances, 4.01 for analysis of ratios, 3.98 for interim data, 3.50 for consideration of non-financial data and information, and 3.45 for budgets and forecasts prepared by the client.

With reference to the development of expectations for operating costs and general expenses account for continuing audit clients (Q10), the mean of the participants' responses was 4.50 for comparisons of balances, 3.93 for analysis of ratios, 3.88 for interim data, 3.53 for consideration of non-financial data and information, and 3.35 for budgets and forecasts prepared by the client. Based on the mean of the respondents' responses in Q9 and Q10, auditors appear to rely on comparisons of balances, ratio analysis, and interim data more than non-financial data and information when developing expectations for operating costs and general expenses account balances.

A paired sample t-test was utilized to compare between auditors' consideration of non-financial data and information from one side and each of the comparisons of balances, analysis of ratios, client's budgets and forecasts, and interim data in developing expectations for operating costs and general expenses account balances for continuing audit clients. The significance level used in this test is 0.05 . The results indicated that there is a statistically significant difference in favor of each of the comparisons of balances $(p=0.000, t=-4.777)$ and the analysis of ratios $(p=0.005$, $\mathrm{t}=-3.007$ ) against the consideration of non-financial data and information during the development of expectations for operating costs and general expenses account balances. Consequently, it may be said that auditors seem to depend more on financial data and information than non-financial data and information in developing expectations for operating costs and general expenses account balances. This is consistent with the findings of previous studies. Hirst and Koonce (1996, p. 463) stated that:

"Auditors spend considerable time gathering and evaluating financial and nonfinancial information about the client and its industry. However, when they develop their expectations for account balances or ratios, we observed that they tend not to rely heavily on such information. Twenty-five of 26 auditors indicated that APs [Analytical Procedures] at planning are generally performed account by account at the financial statement level for both the balance sheet and income statement." 


\subsubsection{Capital Gains and Losses Account Expectations}

Regarding the development of expectations for capital gains and losses account balances for a new audit client (Q11), the mean of the participants' responses for the use of the audit techniques was 4.22 for comparisons of balances, 3.53 for interim data, 3.45 for consideration of non-financial data and information, 3.30 for analysis of ratios, and 2.88 for budgets and forecasts prepared by the client.

Concerning the development of expectations for capital gains and losses account balances for a continuing audit client (Q12), the mean of the respondents' responses for the use of the audit techniques was 4.20 for comparisons of balances, 3.42 for interim data, 3.40 for consideration of non-financial data and information, 3.30 for analysis of ratios, and 2.85 for budgets and forecasts prepared by the client. From the mean of the participants' responses for Q11 and Q12, auditors appear to rely on comparisons of balances, interim data, and non-financial data and information to develop expectations for capital gains and losses account balances more than their reliance on analysis of ratios and budgets and forecasts of the audit client.

A paired sample t-test was performed to compare between auditors' consideration of non-financial data and information from one side and each of the comparisons of balances, analysis of ratios, client's budgets and forecasts, and interim data in developing expectations for capital gains and losses account balances for continuing audit clients. The results indicated that there is only one statistically significant difference in favor of comparisons of balances $(p=$ $0.001, \mathrm{t}=-3.481)$ against the consideration of non-financial data and information during the development of expectations for capital gains and losses account balances in an audit engagement. All other results were statistically insignificant at a significance level of 5 percent. Therefore, it might be said that auditors seem to relatively increase their dependence on non-financial data and information when developing expectations for capital gains and losses account balances.

Some of the respondents expressed that they tend to depend more on non-financial data and information in developing expectations for capital gains and losses account balances because capital gains and losses are usually not a result of the normal operations of an organization. Furthermore, some respondents expressed that capital gains and losses are not found in the financial statements of all audit clients every year, and that capital gains and losses typically require further declarations and justification in financial statements footnotes. Therefore, it may be difficult to develop expectations for capital gains and losses account balances based solely on financial data.

\subsection{Sources of Information Used by Auditors to Find Explanations for Unexpected Trends}

Respondents were requested to express on a five-point scale (where $1=$ rarely, $2=$ sometimes, $3=$ usually, $4=$ frequently, and $5=$ always) how often do they look for explanations from the following sources in case auditors observe a material unexpected trend in the financial statements of an audit client:

1. Ask the staff of the client for an explanation.

2. Generate own explanation.

3. Ask other members of the audit team.

4. Look at prior years' work papers.

Respondents were asked the same question two times: one time in relation to the planning stage (Q13) and another time in relation to the substantive testing stage of an audit (Q14).

With reference to the planning stage of an audit (Q13), the mean of the respondents' responses was 4.43 for asking the staff of the audit client for an explanation, 4.15 for looking at prior years' work papers, 3.45 for asking other members of the audit team, and 3.33 for generating own explanation.

With reference to the substantive testing stage of an audit (Q14), the mean of the respondents' responses was 4.55 for asking the staff of the audit client for an explanation, 4.20 for looking at prior years' work papers, 3.55 for asking other members of the audit team, and 3.40 for generating own explanation. From the mean of the participants' responses for Q13 and Q14, auditors appear to depend on the inquiries of the audit client staff more than looking at prior years' work papers, asking other members of the audit team, and generating own explanation.

A paired sample t-test was performed to compare between participants responses in relation to the use of the above-mentioned information sources by auditors during each of the planning stage and substantive testing stage of an audit. All the results of the paired sample t-test were statistically insignificant at a significance level of 5 percent. Accordingly, it seems that there is no statistically significant difference between the auditors' usage of the 
above-mentioned sources of information during the planning stage and the substantive testing stage to find explanations for any unexpected trends during the performance of an audit.

During the interviews, respondents demonstrated that when they approach the audit client staff requesting justification for any abnormal trends in the financial statements, this does not mean that they accept the responses received from the audit client personnel without further investigation of the matter. The majority of the respondents emphasized that they usually evaluate the client's staff explanations for reasonableness before deciding whether or not to depend on such explanations. Furthermore, all the respondents indicated that the materiality of the matter in question usually help in deciding the next step that the auditor should take after obtaining any information from the audit client. Some respondents also mentioned that they may depend on prior years' work papers as corroborating evidence to assess the reasonableness of the client's staff explanations. Besides, several respondents indicated that sometimes they tend to approach non-financial client personnel (i.e., client personnel far from the accounting department) for further investigation of the matter. Respondents indicated that non-financial client personnel are more likely to be objective and have a broader business focus than the accounting staff, and may provide the auditor with useful information in setting and evaluating expectations.

\section{Summary and Concluded Remarks}

The present study is based on a field study performed in Egypt during the year 2014. The present study deals with auditors' usage of non-financial data and information to verify the validity of the financial performance of an audit client during the assessment of the risk of material misstatement. In addition, an attempt is made in the current study to investigate how auditors tend to search for explanations for unexpected trends existing in the financial statements of an audit client. The present study is based on a questionnaire in addition to in-depth interviews with auditors working at the branches of the international big four audit firm in Egypt.

The results of the present study could be summarized in the following points:

- Auditors are likely to consider non-financial data and information related to general economic conditions and industry trends as well as market share of the audit client more than information related to the audit client's competitors and customers when assessing the risk of material misstatements during an audit engagement.

- Most of the respondents (12 out of 15 audit managers and partners) stated that they would accept a new client with declining trends of non-financial data and information.

- The results of the present study show that auditors usually check the reliability of non-financial information before depending on such information in the assessment of the risk of material misstatement.

- Auditors frequently perform comparisons between financial and non-financial data and information when assessing the risk of material misstatements for audit clients. However, respondents expressed that when they find inconsistencies between financial and non-financial data and information of an audit client, they usually tend to investigate the matter closely by performing tests of details of balances and/or transactions before judging that there is a fraud or material misstatement in the financial statements of an audit client.

- Auditors seem to depend more on financial data and information than on non-financial data and information in developing expectations for operating costs and general expenses account balances.

- Auditors appear to relatively increase their dependence on non-financial data and information when developing expectations for capital gains and losses account balances.

- Client inquiry is found to be the most frequently used source of information by auditors to find explanations for unusual trends uncovered during an audit engagement, followed by checking prior year work papers, asking other audit team members, and generating self-explanation.

In general, it could be said that auditors in Egypt are likely to increase their dependence on non-financial data and information during the assessment of the risk of material misstatement for an audit client. However, it seems that auditors still prefer to depend on financial data and information more than non-financial data and information when developing expectations about the account balances and ratios of an audit client.

Given the deteriorating general economic conditions in Egypt during the years following the revolution of January 2011, and its effect on the level of business risk faced by firms working in Egypt, it may be said that auditors should attempt to increase their dependence on non-financial data and information to be able to formulate correct expectations about the financial statements of their audit clients. Auditors' attention to non-financial data and information in combination with financial data and information would highlight areas were errors and/or material 
misstatements might exist in the financial statements of an audit client. Audit firms should try to provide training sessions to it's audit personnel about how to collect and analyze non-financial data and information in order for auditors to be aware of the role non-financial data and information could have in verifying the financial data and information reported by an audit client.

\section{Current Research Limitations and Suggestions for Future Research}

This part highlights some limitations that should be taken into consideration when looking at the results of the current study in addition to some recommendations for future research:

1) The results of the current study should not be generalized as the sample size used in the study is considered relatively small. For future research, it is recommended to use larger sample size.

2) The current study was based on a sample dominated by senior auditors. Consequently, a sample that is based on more experienced audit personnel such as audit managers and partners may lead to different results.

3) The present study did not examine the effect of auditors' specialization in a certain sector of the economy or specific industry on the improvement of auditors' assessment of audit risk. Future research could test the effect of specialization on auditors' ability to better understand the business environment of the audit client to reduce audit risk.

\section{References}

American Institute of Certified Public Accountants [AICPA]. (1983). Audit risk and materiality in conducting an audit. Statement on Auditing Standards (SAS) No. 47. New York, NY: AICPA.

American Institute of Certified Public Accountants [AICPA]. (1988). Analytical procedures. Statement on Auditing Standards (SAS) No. 56. New York, NY: AICPA.

American Institute of Certified Public Accountants [AICPA]. (2002). Consideration of fraud in a financial statement audit. Statement on Auditing Standards (SAS) No. 99. New York, NY: AICPA.

Behn, B. K., \& Riley, R. A. (1999). Using nonfinancial information to predict financial performance: The case of the U.S. airline industry. Journal of Accounting, Auditing and Finance, 14(1), 29-56. https://doi.org/10.1177/0148558X9901400102

Bell, T. B., Marrs, F. O., Solomon, I., \& Thomas, H. (1997). Auditing organizations through a strategic-systems lens. New York, NY: KPMG Peat Marwick LLP.

Bell, T. B., Peecher, M. E., \& Solomon, I. (2005). The 21st century public company audit: Conceptual elements of KPMG's global audit methodology. Montvale, NJ: KPMG.

Brazel, J. F., Jones, K. L., \& Prawitt, D. F. (2014). Auditors' reactions to inconsistencies between financial and nonfinancial measures: The interactive effects of fraud risk assessment and a decision prompt. Behavioral Research in Accounting, 26(1), 131-156. https://doi.org/10.2308/bria-50630

Brazel, J. F., Jones, K. L., \& Zimbelman, M. F. (2009). Using nonfinancial measures to assess fraud risk. Journal of Accounting Research, 47(5), 1135-1166. https://doi.org/10.1111/j.1475-679x.2009.00349.x

Brewster, B. E. (2011). How a systems perspective improves knowledge acquisition and performance in analytical procedures. The Accounting Review, 86(3), 915-943. https://doi.org/10.2308/accr.00000040

Cohen, J. R., Krishnamoorthy, G., \& Wright, A. M. (2000). Evidence on the effect of financial and nonfinancial trends on analytical review. Auditing: A Journal of Practice \& Theory, 19(1), 27-48. https://doi.org/10.2308/aud.2000.19.1.27

Dechow, P. M., Ge, W., Larson, C. R., \& Sloan, R. G. (2011). Predicting material accounting misstatements. Contemporary Accounting Research, 28(1), 17-82. https://doi.org/10.1111/j.1911-3846.2010.01041.x

DeFond, M. L., Lim, C. Y., \& Zang, Y. (2016). Client conservatism and auditor-client contracting. The Accounting Review, 91(1), 69-98. https://doi.org/10.2308/accr-51150

Erickson, M., Mayhew, B. W., \& Felix, W. L. (2000). Why do audits fail? Evidence from Lincoln Savings and Loan. Journal of Accounting Research, 38(1), 165-194. https://doi.org/10.2307/2672927

Hassan, Omaima A.G., Giorgioni, Gianluigi, \& Romilly, P. (2006). The extent of financial disclosure and its determinants in an emerging capital market: The case of Egypt. International Journal of Accounting, Auditing and Performance Evaluation, 3(1), 41-67. https://doi.org/10.1504/ijaape.2006.010102 
Hassan, Omaima \& Power, David M. (2009). The usefulness of accounting information; evidence from the Egyptian market. Qualitative Research in Financial Markets, 1(3), 125-141. https://doi.org/10.1108/17554170910997393

Hirst, E., \& Koonce, L. (1996). Audit analytical procedures: A field investigation. Contemporary Accounting Research, 13(2), 457-486. https://doi.org/10.1111/j.1911-3846.1996.tb00511.x

Houston, R. W. (1999). The effects of fee pressure and client risk on audit seniors' time budget decisions. Auditing: A Journal of Practice and Theory, 18(2), 70-86. https://doi.org/10.2308/aud.1999.18.2.70

International Auditing and Assurance Standards Board [IAASB]. (2010). International Standard on Auditing 315: Identifying and assessing the risks of material misstatement through understanding the entity and its environment. Retrieved from http://www.ifac.org/sites/default/files/downloads/a017-2010-iaasb-handbook-isa-315.pdf

Ittner, C. D., \& Larcker, D. F. (1998). Are nonfinancial measures leading indicators of financial performance? An analysis of customer satisfaction. Journal of Accounting Research, 36, 1-35. https://doi.org/10.2307/2491304

Johnstone, K. M. (2000). Client-acceptance decisions: Simultaneous effects of client business risk, audit risk, auditor business risk, and risk adaptation. Auditing: A Journal of Practice \& Theory, 19(1), 1-25. https://doi.org/10.2308/aud.2000.19.1.1

Johnstone, K. M., \& Bedard, J. C. (2004). Audit firm portfolio management decisions. Journal of Accounting Research, 42(4), 659-690. https://doi.org/10.1111/j.1475-679x.2004.00153.x

Knechel, W. R. (2007). The business risk audit: Origins, obstacles, and opportunities. Accounting, Organizations and Society, 32(4-5), 383-408. https://doi.org/10.1016/j.aos.2006.09.005

Knechel, W. R., Salterio, S. E., \& Kochetova-Kozloski, N. (2010). The effect of benchmarked performance measures and strategic analysis on auditors' risk assessments and mental models. Accounting, Organizations and Society, 35(3), 316-333. https://doi.org/10.1016/j.aos.2009.09.004

Marzouk, Mahmoud (2016). Risk reporting during a crisis: evidence from the Egyptian capital market. Journal of Applied Accounting Research, 17(4), 378-396. https://doi.org/10.1108/JAAR-02-2015-0012

Nagar, V. \& Rajan, M. V. (2001). The revenue implications of financial and operational measures of product quality. The Accounting Review, 76(4), 495-513. https://doi.org/10.2308/accr.2001.76.4.495

Public Company Accounting Oversight Board [PCAOB]. (2004). PCAOB Standing Advisory Group Meeting: Financial fraud. Retrieved from http://pcaobus.org/News/Events/Documents/ 09082004_SAGMeeting/Fraud.pdf

Riley, R. A., Pearson, T. A., \& Trompeter, G. (2003). The value relevance of non-financial performance variables and accounting information: The case of the airline industry. Journal of Accounting and Public Policy, 22(3), 231-254. https://doi.org/10.1016/s0278-4254(03)00021-8

Simpson, A. (2010). Analysts' use of nonfinancial information disclosures. Contemporary Accounting Research, 27(1), 249-288. https://doi.org/10.1111/j.1911-3846.2010.01008.x

Trompeter, G., \& Wright, A. (2010). The world has changed-Have analytical procedure practices? Contemporary Accounting Research, 27(2), 669-700.https://doi.org/10.1111/j.1911-3846.2010.01021.x

Wahdan, M.A., \& Van den Herik, H.J. (2012). Egyptian auditing investigated: diagnoses and remedies. International Journal of Economics and Accounting, 3(3/4), pp.365-385. https://doi.org/10.1504/ijea.2012.049078

Wright, A. M. (1988). The impact of prior working papers on auditor evidential planning judgments. Accounting, Organizations, and Society, 13(6),595-606. https://doi.org/10.1016/0361-3682(88)90033-5

\section{Notes}

Note 1. Financial risk is the risk that a potential client's economic condition will deteriorate in either the short or long term (Johnstone, 2000); it is also referred to as client business risk. Audit risk is "the risk that the auditor may unknowingly fail to appropriately modify his opinion on financial statements that are materially misstated" (AICPA, 1983). Auditor business risk is "the risk that the audit firm will suffer a loss resulting from the engagement" (Johnstone, 2000; AICPA, 1983). 